
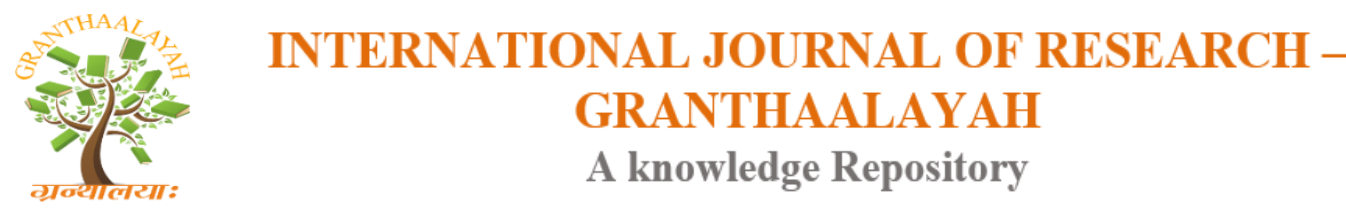

Science

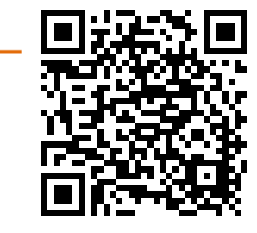

\title{
EFFECT OF SILICON APPLICATION ONTALIOUINE CROCUS SATIVUS (L) CULTIVATION UNDERSALT STRESS
}

\author{
FahimiJamila 1, 2, Bouzoubaâ Zakia *2, AchemchemFouad ${ }^{1}$, SaffajNabil 1, Mamouni \\ Rachid 1 \\ ${ }^{1}$ Laboratories for Agrophysiology and Post Harvest - Research Unit for Natural Resources and \\ Terroir Products (UR RN \& PDT) INRA- CRRA- Agadir \\ 2 Team: Materials, Catalysis and Valorization of Natural Resources, Ibn-Zohr University; \\ Department of Chemistry, FSA. Agadir
}

\begin{abstract}
This study investigates the effect of silicon ( $\mathrm{Si}$ ) application on saffron plantgrown under salt stress. Therefore; Saffron, Crocus sativus L. was grown in different treatments of $\mathrm{NaCl}$ in presence and absence of $1 \mathrm{mM}$ of silicon in its soluble form, orthosilicic acid(H4SiO4). Our results exhibited that the application of silicon enhanced the physiologicalstudied parameters and morphological attributes of saffron stigmas; the length of stigma improvement was $29 \%$ and $41,4 \%$ in saline treatments of $50 \mathrm{mM}$ and $100 \mathrm{mM}$ respectively in presence of silicon compared to the same treatments without silicon, the dry weight of the stigma boosted by $40 \%$ for the treatment of $50 \mathrm{mM}$ of $\mathrm{NaCl}$ and $20 \%$ for $100 \mathrm{mM}$ treatments compared to the same treatments in absence ofsilicon. Siliconaddition ameliorated RWC, total phenolic, anti-radical leaves activity and $\mathrm{K}+$ contents and $\mathrm{K}+/ \mathrm{Na}+$ ration in both roots and leaves. These results suggested that $\mathrm{Si}$ application enhanced saffron plant and improved the weight and length of saffron stigma.
\end{abstract}

Keywords: Saffron Crocus Sativus L; Salinity; Silicon; Stigma;Anti-Radical Activity.

Cite This Article: FahimiJamila, Bouzoubaâ Zakia, AchemchemFouad, SaffajNabil, and Mamouni Rachid. (2018). "EFFECT OF SILICON APPLICATION ONTALIOUINE CROCUS SATIVUS (L) CULTIVATION UNDERSALT STRESS." International Journal of Research Granthaalayah, 6(9), 291-300. https://doi.org/10.5281/zenodo.1443451.

\section{Introduction}

Salinity is the most calamitous abiotic stress which limits the growth and yield of agricultural and horticultural crops worldwide(Charu et al. 2014; Munns, 2005; Shahbaz and Ashraf, 2013). Salt stress causes a major reduction in plants growth(Paul, 2013), it alters almost the physiological and biochemical pathways in the plants(Nabati et al., 2011; Pitman and Läuchli, 2002). According to Jamil et al. (2011), it has been predicted that more than $50 \%$ of the arable land would be salinized by the year 2050. Therefore, an alternative strategy should be adopted to mitigate the negative 
effects of salinity on the plant growth and yield; the application of silicon is declared one of the most appropriate solutions(Liang et al. 2007).

Silicon (Si)is the second most abundant element in the Earth's crust after oxygen. It has been widely reported about the Si functions in the alleviation of stress and enhancement of plant growth(Bouzoubaâ, 1991, 2007; Liang et al., 2007; Ouzounidou et al. 2016). The plant absorbs Si under its form monosilicic acid or orthosilicic acid $\left(\mathrm{H}_{4} \mathrm{SiO}_{4}\right)$ (Matichenkov and Bocharnikova, 2004). Silica accumulating under the cuticle of leaves reduce water loss by transpiration under drought stress(Hodson et al. 2005). Same as in cell vacuoles, it enhances light capture by lodging which promotes photosynthetic activity(Ma et al.,2011). The absorbed siliconboosts plant resistance against salt stress and metal ions such as $\mathrm{Zn}, \mathrm{Al}, \mathrm{Mn}$, and $\mathrm{Cd}$. It also improves activities of non-enzymatic antioxidant and decreasesthe rate of lipid peroxidation(Neumann and Nieden, 2001; Moussa, 2006; Zhu et al., 2004).

Saffron Crocus sativus (L), belonging to Iridaceae family, is traditionally exploited to obtainthe dried stigmas of the flower, which is declared the most expensive spice of the world(SanchezVioque et al., 2012). in traditional medicine, it is used for several effectssuch as cardiotonic, stomachic, antispasmodic(Hosseinzadeh et al., 2009). Moreover, saffron spice shows many pharmacological properties among which, anticonvulsant(Hosseinzadeh and Younesi, 2002), antidepressants, antinociceptive and anti-inflammatory, antioxidant, antitussive, reducing withdrawal syndrome, improving male erectile dysfunction(Razavi and Hosseinzadeh, 2015), acetylcholinesterase inhibiting(Geromichalos et al., 2012), enhancing spatial cognitive abilities after chronic cerebral hypoperfusion(Hosseinzadeh et al., 2012)hypotensive(Kianbakht and Hajiaghaee, 2011), and significant antiproliferative effects on humancells of colorectal cancer(Aung et al., 2009). Morocco products about 3 tons; it presents 1,5\% of the world production, restricted toTaliouine region and it reflects a great reputation nationally and internationally(Lage and Cantrell, 2009). An estimated 75000 blossoms or 225000 hand-picked stigmas are needed to make one pound of saffron, this can explain its market price(Aytekin and Acikgoz, 2008), that makes it a rare spice of great commercial value(Aït Oubahou and El Otmani, 2002)andso, granted to this cultivation a high-value resource for job creation and improvement of family income, especiallyin rural area.

Crocus sativus L. is an important cultivation, it isthe most expensive spice in the globe. On the other hand; salinity is a worrying problem for agriculture which is getting worse, affecting more areas and so causing aserious and continuous progress of saline lands. Therefore, the application of silicate fertilizer may, in fact,mitigate drought stress (Ali et al., 2008), reduce the high demand for irrigation, which in turn would diminish salinization of cropland. Moreover, silicon is not corrosive and pollution-free, accordingly, silicon fertilizer is a high-quality fertilizer for developing ecologically green agriculture (Zhu and Gong, 2014). Due to those facts, the main objective of the proposed study was to evaluate the effects of silicon on biochemical aspects of saffron and morphological attributes of its stigma under salt conditions. 


\section{Materials and Methods}

\section{Plant Material and Growth Conditions}

In order to evaluate the silicon effect on saffron Crocus sativus L. under salinity stress conditions, an experiment as RCBD (Randomize Complete Block Design) in three replications was performed in the greenhouse at The National Institute for Agricultural Research -INRA of Agadir. The experimental treatments concluded: salinityat 2 levels $50 \mathrm{mM} \mathrm{NaCl}, 100 \mathrm{Mm} \mathrm{NaCl}$ with $1 \mathrm{mM}$ calcium silicate. The pots were prepared for the cultivation of saffron corms filling with sand and peat with the rate of 1:1; then all pots were irrigated with water. 24 hours later three saffron corms were planted in each pot, then each pot was uniformly irrigated with the water treatments. All agricultural operations such as weeds removal, irrigation with salt water, were done until the end of the growth period (about 4 months)(Fahimi et al., 2017). Some parameters of saffron were measured and recorded during experiment time.

\section{Extraction and Analyze of Mineral Elements}

After drying, the samples (leavesand roots) were reduced to fine powder by means of a ball mill. Known quantities of vegetable powder previously dried in an oven are placed in the pellets in the presence of a known volume of $0.5 \%$ nitric acid. The dry matter/volume ratio is $20 \mathrm{mg}$ of dry matter for $50 \mathrm{ml}$ of acid. Hermetically closed pills to avoid concentration of the extracts by evaporation are stirred periodically 4 to 5 times per day. The extracts were then filtered on filter paper without ash and are therefore ready for the determination of the mineral elements(Hamrouni et al., 2011). $\mathrm{Na}$ and $\mathrm{K}$ in the sample solution were analyzed using a flame photometer.

\section{Relative Water Content}

The Relative water content (RWC) measurement allows knowing the relative water content of the plant. The calculation of this value requires the measurement of 3 parameters: fresh mass (FM), imbibedmass(IM) and dry mass (DM). The fresh mass is weighed immediately after harvesting; the imbibed mass is measured after $24 \mathrm{~h}$ of immersion in distilled water at $4{ }^{\circ} \mathrm{C}$. and the dry mass (DM) is determined after 24 hours of drying the sample in an oven at $80^{\circ} \mathrm{C}$. The RWC is calculated by applying the following equation (Dany, 2013)

$\mathrm{RWC}=100 *(\mathrm{FM}-\mathrm{DM}) /(\mathrm{IM}-\mathrm{DM})$

The number of plants is fifteen samples for each treatment.

\section{Total Phenolic Content}

To extract the polyphenols from different parts of our plant by maceration, we opted for the protocol described by Romani et al. (2006)with some modifications: $1 \mathrm{~g}$ of leaves powder is macerated at room temperature for $12 \mathrm{~h}$ with $10 \mathrm{ml}$ of aqueous solutions of the methanol $70 \%$. After filtration on a muslin tissue, the filtrates are centrifuged for $20 \mathrm{~min}$ at $4000 \mathrm{rpm}$ at room temperature, filtered on filter paper $\mathrm{N}^{\circ} 1$ and stored at $4{ }^{\circ} \mathrm{C}$ until use. The total phenolic of the extracts were determined using the Folin and Ciocalteu reagent, following the method described by Singleton and Rossi with slight modifications. $100 \mu \mathrm{l}$ of saffron leaves extract are mixed with $500 \mu \mathrm{l}$ of the FolinCiocalteu reagent, after $5 \mathrm{~min}$ is added $400 \mu \mathrm{l}$ of $\mathrm{Na}_{2} \mathrm{CO}_{3}$ with $7.5 \%$ (w/v)) and the volume was made up to $3 \mathrm{ml}$ with distilled water. The reaction was kept in the dark for $30 \mathrm{~min}$ and after centrifuging the absorbance of blue color from different samples was measured at 
$765 \mathrm{~nm}$. The phenolic content was calculated as gallic acid equivalents GAE/g of dry plant material on the basis of a standard curve of gallic acid. All determinations were carried out in triplicate. Sample and standard readings were made using a spectrophotometer at $765 \mathrm{~nm}$ against the reagent blank.

\section{Antioxidant Activity Assay}

The antioxidant activity of the prepared leave extracts from saffronwas assessed by measuring the scavenging power of free radical 2,2-diphenyl-1-picrylhydrazyl(DPPH) according to the method of Hossain et al., (2014). All extracts were dissolved in methanol and assayed in a quad. The crude extract such was taken in a test tube and dissolved with $10 \mathrm{~mL}$ of methanol. Five concentrations such as $12.5 \mu \mathrm{g} / \mathrm{mL}, 25 \mu \mathrm{g} / \mathrm{mL}, 50 \mu \mathrm{g} / \mathrm{mL}, 100 \mu \mathrm{g} / \mathrm{mL}$ and $200 \mu \mathrm{g} / \mathrm{mL}$ were prepared through dilution method. DPPH (3.3 mg) was taken in a 100 mlvolumetric flask and dissolved with methanol. Each prepared concentration $(1.5 \mathrm{~mL})$ was taken in a test tube and added $2.5 \mathrm{~mL}$ of DPPH solution. The prepared mixture was shaken gently by hand and kept in dark place for 90 min. The absorbance of the samples was measured by using UV-visible spectrophotometer at wavelength $517 \mathrm{~nm}$. Finally, the inhibition of free radical DPPH percentage I (\%) is calculated using the following formula:

Inhibition $(\%)=100 \times($ Acontrol - Atest $) /$ Acontrol

Where Acontrol is the absorbance of the control (containing all reagents without the test product) and Atest is the absorbance of the test compound (containing all reagents and the test product). The value IC50 $(\mu \mathrm{g} / \mathrm{ml})$ is calculated from the graph of the DPPH scavenging effect percentage against the sample concentration and it is used to characterize the antioxidant activity of different examined extracts, the extract concentration required to cause a 50\% inhibition. A lower IC50 value corresponds to a higher antioxidant activity of the plant extract. All tests were performed in quadruplicate for each concentration.

\section{Length and Weight of Saffron Stigma}

After saffron stigma harvest, we measure its length using a ruler. The weight is measured by precision scale after its dry.

\section{Statistical Analysis}

Data were analyzed using the statistical software (Minitab 17); mean data were compared by Tukey's test $(\mathrm{p} \leq 0.05)$.

\section{Results and Discussion}

The higher dry weight of saffron stigma was obtained in the treatment of silicon; the addition of silicon increased markedly the dry weight of the stigma by $40 \%$ for the treatment of $50 \mathrm{mM}$ of $\mathrm{NaCl}$ and $20 \%$ for $100 \mathrm{mM}$ treatments compared to the same treatments without silicon. Same as the length of stigma, the value was $6,35 \mathrm{~cm}$ in the treatment of silicon, the percentage of its improvement is $52,3 \%$ compared to the same treatment without $\mathrm{Si}, 29 \%$ and $41,4 \%$ in saline treatments of $50 \mathrm{mMand} 100 \mathrm{mM}$ respectively (Table 1). Thus, the supply of silicon augmented the stigma of Crocus sativus, those results are in agreement with many studies that reported the 
role of silicon in enhancing the agricultural crop quality, growth and yield(Ahmed et al., Khurshid, 2011; Balakhnina and Borkowska, 2013; Korndörfer and Lepsch, 2001).

Table 1: Dry weight and length of saffron stigma of plants grown under salt condition in absence and presence of Silicon

\begin{tabular}{|l|l|l|}
\hline Treatment & Dry weight of the stigma $(\mathbf{m g})$ & Length of the stigma $(\mathbf{c m})$ \\
\hline $\mathbf{0 m M ~ N a C l}$ & $0,006 \pm 0,0008^{\mathrm{ab}}$ & $4,17 \pm 0,47^{\mathrm{c}}$ \\
\hline $\mathbf{5 0} \mathbf{m M ~ N a C l}$ & $0,005 \pm 0,002^{\mathrm{ab}}$ & $5,72 \pm 1,07^{\mathrm{b}}$ \\
\hline $\mathbf{1 0 0} \mathbf{m M ~ N a C l}$ & $0,005 \pm 0,0012^{\mathrm{b}}$ & $5,15 \pm 0,43^{\mathrm{bc}}$ \\
\hline $\mathbf{0 ~ N a C l} / \mathbf{+} \mathbf{S i}$ & $0,007 \pm 0,0011^{\mathrm{a}}$ & $6,35 \pm 1,04^{\mathrm{b}}$ \\
\hline $\mathbf{5 0} \mathbf{m M ~ N a C l} / \mathbf{+ S i}$ & $0,007 \pm 0,0012^{\mathrm{a}}$ & $7,38 \pm 1,23^{\mathrm{a}}$ \\
\hline $\mathbf{1 0 0} \mathbf{m M ~ N a C l}+\mathbf{S i}$ & $0,006 \pm 0,002^{\mathrm{ab}}$ & $7,28 \pm 1,93^{\mathrm{a}}$ \\
\hline
\end{tabular}

Data are expressed as mean values \pm SD. Values followed by different letters $(a, b, c)$ in the same column are significantly different at $\mathrm{P} \leq 0,05$

Plant growth is greatly combined with many physiological factors such as RWC; our present data showed that the lower percentages of RWC were obtained in the control treatment also under salt conditions (fig 1), while the application of silicon promoted the RWC in stressed conditions, it raised the RWC by $6 \%$ and $8 \%$ in the treatments of $50 \mathrm{mM}$ and $100 \mathrm{mM}$ of $\mathrm{NaCl}$ respectively, Hodson et al., (2005) reported the same thing, which it may due to the accumulation of silicon under the cuticle of leaves that leads to reducing water loss by transpiration under drought stress. Moreover, Ma reported that silicon can strengthen xylem vessels (Ma, 2004), that are structures responsible for water transport into the plant (McElrone et al., 2004). Consequently, this firm xylem vessels can just allow to plants a resistance in stressful environments, likewise enhancing water absorbed by plants (Sperry et al., 2002). Abbas et al., (2015)as well demonstrated that the application of silicon enhanced the RWC of okra (Abelmoschus esculentus) species.

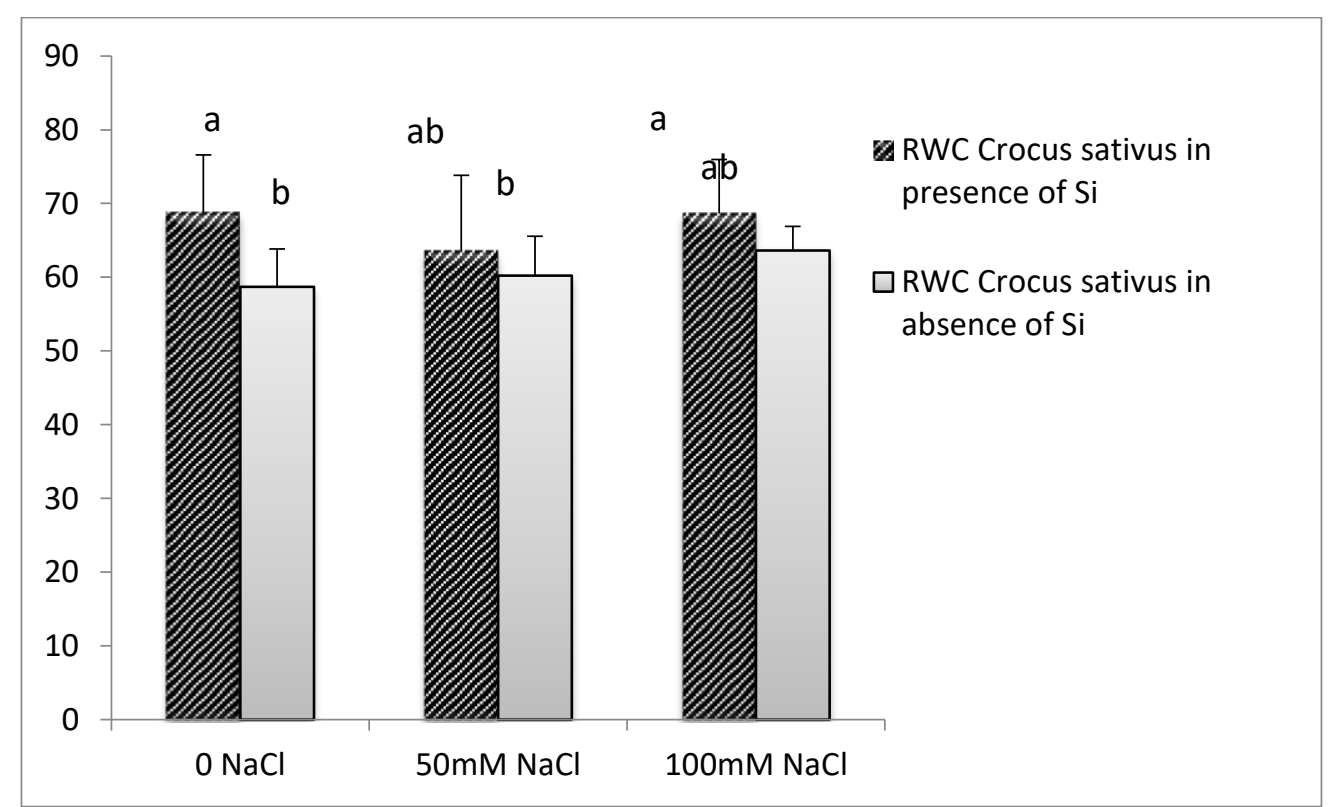

Figure 1: Relative water contents in Crocus sativus plant under different treatment of $\mathrm{NaCl}$ with or without Silicon 
Data are expressed as mean values \pm SD. Values followed by different letters $(a, b)$ are significantly different at $\mathrm{P} \leq 0,05$

Table 2: Leaf polyphenol concentrations and anti-radical activities in TaliouineCrocus sativus L. leaves under different treatments of $\mathrm{NaCl}$ with or without Silicon

\begin{tabular}{|c|c|c|}
\hline Treatment & Leaves total phenol contents $\mu \mathrm{g}$ GAA g-1 DW & IC50 $\mu \mathrm{g} / \mathrm{ml}$ \\
\hline $\mathrm{O} \mathrm{NaCl} / \mathrm{OSi}$ & $83,26 \pm 2,51^{\mathrm{a}}$ & $195.13 \pm 5.39^{\mathrm{bc}}$ \\
\hline $50 \mathrm{mM} \mathrm{NaCl} / \mathbf{- S i}$ & $93,02 \pm 5,91^{\mathrm{a}}$ & $227.91 \pm 41.80^{\mathrm{ab}}$ \\
\hline $100 \mathrm{mM} \mathrm{NaCl} / \mathrm{-Si}$ & $80,00 \pm 28^{\mathrm{a}}$ & $266.22 \pm 25.10^{\mathrm{a}}$ \\
\hline $\mathbf{0} \mathrm{NaCl} /+\mathrm{Si}$ & $94,22 \pm 2,13^{\mathrm{a}}$ & $181.58 \pm 13.71^{\mathrm{bc}}$ \\
\hline $50 \mathrm{mM} \mathrm{NaCl} / \mathrm{Si}$ & $94,07 \pm 2,92^{\mathrm{a}}$ & $175.80 \pm 9.70^{\mathrm{c}}$ \\
\hline $100 \mathrm{mM} \mathrm{NaCl} / \mathrm{Si}$ & $99,15 \pm 2,92^{\mathrm{a}}$ & $156.65 \pm 12.64^{\mathrm{c}}$ \\
\hline
\end{tabular}

Data are expressed as mean values \pm SD. Values followed by different letters (a, b, c and d) in the same column are significantly different at $\mathrm{P} \leq 0,05$

Table 2: $\mathrm{Na}$, $\mathrm{K}$ concentrations $(\mathrm{ppm})$ and $\mathrm{K}+\mathrm{Na}+$ ratio in leaves and roots of saffron grown under different treatments of $\mathrm{NaCl}$ in absence and presence of Silicon.

\begin{tabular}{|c|c|c|c|c|c|c|}
\hline $\begin{array}{c}\text { Treatme } \\
\mathbf{n t}\end{array}$ & $\begin{array}{c}\mathbf{N a}^{+} \text {contents } \\
\text { in } \\
\text { leaves(ppm) }\end{array}$ & $\begin{array}{c}\mathbf{K}^{+} \text {contents } \\
\text { in leaves } \\
(\mathbf{p p m})\end{array}$ & $\begin{array}{c}\mathbf{K}^{+} / \mathbf{N a}^{+} \mathbf{R a t} \\
\text { io in leaves }\end{array}$ & $\begin{array}{c}\mathbf{N a}^{+} \\
\text {contents in } \\
\text { roots (ppm) }\end{array}$ & $\begin{array}{c}\mathbf{K}^{+} \text {contents } \\
\text { in roots } \\
(\mathbf{p p m})\end{array}$ & $\begin{array}{c}\mathbf{K}^{+} / \mathbf{N a}^{+} \\
\text {ratio in } \\
\text { roots }\end{array}$ \\
\hline $\begin{array}{c}\mathbf{0} \mathbf{~ N a C l} / \mathbf{0} \\
\mathbf{S i}\end{array}$ & $15,67 \pm 0,91 \mathrm{ab}$ & $9,00 \pm 2,65 \mathrm{~b}$ & $0,58 \pm 0,19 \mathrm{~b}$ & $43,93 \pm 4,03 \mathrm{a}$ & $22,63 \pm 3,32 \mathrm{~b}$ & $0,52 \pm 0,09 \mathrm{c}$ \\
\hline $\begin{array}{c}\mathbf{5 0} \mathbf{~ m M} \\
\mathbf{N a C l} / \mathbf{- S i}\end{array}$ & $16,17 \pm 0,47 \mathrm{a}$ & $6,20 \pm 0,72 \mathrm{~b}$ & $0,38 \pm 0,05 \mathrm{~b}$ & $45,83 \pm 1,79 \mathrm{a}$ & $12,70 \pm 4,21 \mathrm{c}$ & $0,28 \pm 0,08 \mathrm{~d}$ \\
\hline $\begin{array}{c}\mathbf{1 0 0} \mathbf{~ m M} \\
\mathbf{N a C l} / \mathbf{- S i}\end{array}$ & $17,53 \pm 0,5 \mathrm{a}$ & $6,47 \pm 2,23 \mathrm{~b}$ & $0,37 \pm 0,12 \mathrm{~b}$ & $48,83 \pm 2,93 \mathrm{a}$ & $7,10 \pm 0,87 \mathrm{c}$ & $0,15 \pm 0,02 \mathrm{~d}$ \\
\hline $\begin{array}{c}\mathbf{0} \mathbf{~ N a C l} / \\
\mathbf{+ S i}\end{array}$ & $12,93 \pm 1,62 \mathrm{c}$ & $15,00 \pm 0,90 \mathrm{a}$ & $1,17 \pm 0,16 \mathrm{a}$ & $21,50 \pm 0,35 \mathrm{c}$ & $41,17 \pm 3,35 \mathrm{a}$ & $1,92 \pm 0,16 \mathrm{a}$ \\
\hline $\begin{array}{c}\mathbf{5 0} \mathbf{~ m M} \\
\mathbf{N a C l} / \\
\mathbf{+ S i}\end{array}$ & $13,57 \pm 0,45 \mathrm{bc}$ & $17,07 \pm 0,95 \mathrm{a}$ & $1,26 \pm 0,10 \mathrm{a}$ & $31,43 \pm 1,5 \mathrm{~b}$ & $40,43 \pm 2,91 \mathrm{a}$ & $1,29 \pm 0,03 \mathrm{~b}$ \\
\hline $\begin{array}{c}\mathbf{1 0 0} \mathbf{~ m M} \\
\mathbf{N a C l} / \\
\mathbf{+ S i}\end{array}$ & $15,70 \pm 0,44 \mathrm{ab}$ & $18,00 \pm 1,90 \mathrm{a}$ & $1,15 \pm 0,15 \mathrm{a}$ & $35,87 \pm 3,72 \mathrm{~b}$ & $40,97 \pm 2,73 \mathrm{a}$ & $1,15 \pm 0,05 \mathrm{~b}$ \\
\hline
\end{tabular}

Data are expressed as mean values \pm SD. Values followed by different letters (a, b, c and d) in the same column are significantly different at $\mathrm{P} \leq 0,05$

In stressful environments, plants act by producing different osmolytes and antioxidant compounds as total phenolic (Ashraf and Foolad, 2007).In the previous study, our results exhibited proline was accumulated in leaves of the saffron plant grown at the high concentration of salinity, same as the contents of total sugar in leaves (Fahimi et al., 2017). Total phenolics are cellular solutes which minimize environment stress (Singh, 2004); in table 2, salt stress didn't affect total phenolic contents. Whereas, the amount of silicon application augmented leaves total phenol contents of saffron but not significantly, it is $13 \%$ in absence of $\mathrm{NaCl}$ and $4 \%$ in presence of $\mathrm{NaCl}$ for both concentrations $50 \mathrm{mM} \mathrm{NaCl}$ and $100 \mathrm{mM} \mathrm{NaCl}$. Leaves total phenol contents and leaves antiradical activity showed a strong negative correlation (-0.76), silicon-treated plants showed 
higheranti-radicalactivity. The present data are in agreement with what Abbas et al., (2015)found in his work on Okra-7080, it presented maximum total phenolics when treated with Si. Therefore, they concluded that the application of silicon increased antioxidant activities and level of certain osmolytes and reduction in toxic ions $(\mathrm{Na}$ and $\mathrm{Cl}$ ) which led to enhance plant biomass, total chlorophyll contents, photosynthetic activity, RWC and total soluble proteins under $\mathrm{NaCl}$ stress. Hence, it is suggested that $\mathrm{Si}$ is an excellent stress-mitigating agent for protecting plants from $\mathrm{NaCl}$ induced toxicity(Abbas et al., 2015). Moreover,Sahebi et al.,(2015)reviewed that supply of Si mitigates stress and boosts plant growth under abiotic stress such as salinity. The apoplastic transport of $\mathrm{Na}+$ and $\mathrm{Cl}$ - ions was decreased by $\mathrm{Si}$ deposition under salt conditions. Zhu and Gong reported that silicon mechanisms under salt conditions comprise the aspects of upkeeping optimal water content, ameliorating photosynthesis activity and curbing transpiration rate, mitigating ion toxicity thus reducing oxidative stress, and biosynthetic regulation of solutes and plant hormones (Zhu and Gong, 2014). Likewise, in their work Manivannan et al., (2016)revealed that Si protected Capsicum from salinity stress by alleviating oxidative stress and enhancing growth by regulating photosynthesis, nutrient management, and antioxidant enzyme metabolism.In this study, $\mathrm{Na}^{+}$ concentrations in both leaves and roots of Crocus sativus were higher under salinity conditions, but silicon application decreased significantly sodium concentration in both leaves and roots in salt conditions especially in roots, the percentages of decrease of sodium contents in leaves were $16,17 \%$ and $10,53 \%$ for the salt treatments of $50 \mathrm{mM}$ and $100 \mathrm{mM}$ of $\mathrm{NaCl}$ respectively in presence of Si compared to the same treatments in absence of Si. However, the percentages were more important in roots, $31,4 \%$ and $26,5 \%$ in $50 \mathrm{mM}$ and $100 \mathrm{mM} \mathrm{NaCl}$ treatments with Si application respectively compared to the same treatments in absence of Si. Moreover, stress conditions reduced noticeably $\mathrm{K}^{+}$concentrations in both leaves and roots tissues of Crocus sativus compared with the treatments without silicon. Leaf and root potassium concentrations were significantly increased when $\mathrm{Si}$ was added specially to salt treatments. In leaves, the contents were more than twice for both salt treatments $50 \mathrm{mM}$ and $100 \mathrm{mM}$ with Si supply compared to the same treatments without $\mathrm{Si}$. In roots as well, the $\mathrm{K}^{+}$concentrations were three times more important for salt treatment of $50 \mathrm{mM}$ with $\mathrm{Si}$ than its concentrations in absence of $\mathrm{Si}$, and five times for salt treatment $100 \mathrm{mMin}$ presence of $\mathrm{Si}$. In addition to that, the addition of $\mathrm{Si}$ increased $\mathrm{K}^{+} / \mathrm{Na}^{+}$ratio in leaves and roots as well(Table 3).Various studies reported that $\mathrm{Si}$ may mitigate salt stress by affecting $\mathrm{Na}^{+}$and $\mathrm{K}^{+}$concentrations(Ashraf et al., 2010; Garg and Bhandari, 2016). For example, in their work on Cicer arietinum L., Garg and Bhandari (2016) found that the addition of silicon under salt conditions reduced the $\mathrm{Na}^{+}$uptake in roots and in leaves but it enhanced $\mathrm{K}^{+}$concentration as well as the $\mathrm{K}+/ \mathrm{Na}+$ ratio.

\section{Conclusion}

Regarding our results, the inclusion of silicon to Crocus sativus L. improved biochemical parameters of Taliouine Croccus sativus (L) plant and morphological attributes of its stigma grown under salt stress through increasing RWC, decreasing the uptake of $\mathrm{Na}^{+}$as a toxic ion in roots and its translocation to leaves while promoting $\mathrm{K}^{+}$uptake in both roots and leaves, slight enhancement of leaves anti-radical activity and total phenolic which lead to promote the stigmas of the crop.

\section{References}

[1] Abbas, T., Balal, R. M., Shahid, M. A., Pervez, M. A., Ayyub, C. M., Aqueel, M. A., \&Javaid, M. M. (2015). Silicon-induced alleviation of $\mathrm{NaCl}$ toxicity in okra (Abelmoschus esculentus) is 
associated with enhanced photosynthesis, osmoprotectants and antioxidant metabolism. Acta Physiologiae Plantarum, 37(2). https://doi.org/10.1007/s11738-014-1768-5

[2] Ahmed, M., Fayyaz-ul-Hassen, \& Khurshid, Y. (2011). Does silicon and irrigation have impact on drought tolerance mechanism of sorghum? Agricultural Water Management, 98(12), 1808-1812. https://doi.org/10.1016/j.agwat.2011.07.003

[3] Aït Oubahou Ahmed; El Otmani Mohamed. (2002). La culture du Safran, (37), 77-80.

[4] Ali, M. A., Lee, C. H., Kim, P. J., \& Rice, P. (2008). Effect of silicate fertilizer on reducing methane emission during rice cultivation, 597-604. https://doi.org/10.1007/s00374-007-0243-5

[5] Ashraf, M., Akram, N. A., Arteca, R. N., \& Foolad, M. R. (2010). The physiological, biochemical and molecular roles of brassinosteroids and salicylic acid in plant processes and salt tolerance. Critical Reviews in Plant Sciences, 29(3), 162-190. https://doi.org/10.1080/07352689.2010.483580

[6] Ashraf, M., \& Foolad, M. R. (2007). Roles of glycine betaine and proline in improving plant abiotic stress resistance. Environmental and Experimental Botany, 59(2), 206-216. https://doi.org/10.1016/j.envexpbot.2005.12.006

[7] Aung, H. H., Wang, C. Z., Ni, M., Fishbein, A., Mehendale, S. R., Xie, J. T., \& Yuan, C. S. (2009). NIH Public Access, 29(3), 175-180.

[8] Aytekin, A., \& Acikgoz, A. O. (2008). Hormone and microorganism treatments in the cultivation of saffron (Crocus Sativus L.) plants. Molecules, 13(5), 1135-1147. https://doi.org/10.3390/molecules13051135

[9] Balakhnina, T., \& Borkowska, A. (2013). Effects of silicon on plant resistance to environmental stresses: review. International Agrophysics, 27(2), 225-232. https://doi.org/10.2478/v10247-0120089-4

[10] Bouzoubaâ, Z. (1991). Etude des rôles de la silice dans les mécanismes de tolérance à la sécheresse chez quelques espèces de gr ande culture. PhD thesis, U.S.T.L. Montpellier II.160p.

[11] Bouzoubaâ, Z. (2007). Effet du Silicium sur l'Amélioration de la Germination de l'Arganier, Argania spinosa (L). Skeels, en conditions de Salinité et de Déficit Hydrique. Ann de La Recherche Forestière Au Maroc., 38, 35.

[12] Charu, S., Vibhuti, Kiran, B., \& Surendra Singh, B. (2014). Influence of boron on seed germination and seedling growth of wheat (Triticum aestivum L.). African Journal of Plant Science, 8(2), 133139. https://doi.org/10.5897/AJPS2014.1148

[13] Dany, M. (2013). Etude du transport des sucres dans les racines d'Arabidopsis thaliana au cours de son cycle de développement et en réponse à un stress osmotique.

[14] Fahimi, J., Bouzoubaâ, Z., Achemchem, F., Saffaj, N., \& and Mamouni, R. (2017). Effect of silicon on improving salinity tolerance of Taliouine Crocus sativus L.. Acta Hort. (ISHS) 1184:219-228, (https://doi.org/10.17660/ActaHortic.2017.1184.31), 1184:219-228.

[15] Garg, N., \& Bhandari, P. (2016). Interactive effects of silicon and arbuscular mycorrhiza in modulating ascorbate-glutathione cycle and antioxidant scavenging capacity in differentially salttolerant Cicer arietinum L. genotypes subjected to long-term salinity. Protoplasma, 253(5), 13251345. https://doi.org/10.1007/s00709-015-0892-4

[16] Geromichalos, G. D., Lamari, F. N., Papandreou, M. A., Trafalis, D. T., Margarity, M., Papageorgiou, A., \& Sinakos, Z. (2012). Saffron as a source of novel acetylcholinesterase inhibitors: Molecular docking and in vitro enzymatic studies. Journal of Agricultural and Food Chemistry, 60(24), 6131-6138. https://doi.org/10.1021/jf300589c

[17] Hamrouni, L., Hanana, M., Abdelly, C., \& Ghorbel, A. (2011). Exclusion du chlorure et inclusion du sodium: Deux mécanismes concomitants de tolérance à la salinité chez la vigne sauvage Vitis vinifera subsp. sylvestris (var. "séjnène"). Biotechnology, Agronomy and Society and Environment, 15(3), 387-400.

[18] Hodson, M. J., White, P. J., Mead, A., \& Broadley, M. R. (2005). Phylogenetic variation in the silicon composition of plants. Annals of Botany, 96(6), 1027-1046.

https://doi.org/10.1093/aob/mci255 
[19] Hossain, M. A., Kalbani, M. S. A. Al, Farsi, S. A. J. Al, Weli, A. M., \& Al-Riyami, Q. (2014). Comparative study of total phenolics, flavonoids contents and evaluation of antioxidant and antimicrobial activities of different polarities fruits crude extracts of Datura metel L. Asian Pacific Journal of Tropical Disease, 4(5), 378-383. https://doi.org/10.1016/S2222-1808(14)60591-0

[20] Hosseinzadeh, H., Modaghegh, M. H., \& Saffari, Z. (2009). Crocus sativus L. (saffron) extract and its active constituents (crocin and safranal) on ischemia-reperfusion in rat skeletal muscle. Evidence-Based Complementary and Alternative Medicine, 6(3), 343-350. https://doi.org/10.1093/ecam/nem125

[21] Hosseinzadeh, H., Sadeghnia, H. R., Ghaeni, F. A., Motamedshariaty, V. S., \& Mohajeri, S. A. (2012). Effects of saffron (Crocus sativus L.) and its active constituent, crocin, on recognition and spatial memory after chronic cerebral hypoperfusion in rats. Phytotherapy Research, 26(3), 381386. https://doi.org/10.1002/ptr.3566

[22] Hosseinzadeh, H., \& Younesi, H. M. (2002). stigma and petal extracts in mice, 8, 1-8.

[23] Jamil, A., Riaz, S., Ashraf, M., \& Foolad, M. R. (2011). Gene Expression Profiling of Plants under Salt Stress. Critical Reviews in Plant Sciences, 30(5), 435-458. https://doi.org/10.1080/07352689.2011.605739

[24] Kianbakht, S., \& Hajiaghaee, R. (2011). Anti-hyperglycemic effects of saffron and its active constituents, crocin and safranal, in alloxan-induced diabetic rats. Journal of Medicinal Plants, 10(39), 82-89.

[25] Korndörfer, G. H. ., \& Lepsch, I. (2001). Chapter 7 Effect of silicon on plant growth and crop yield. Studies in Plant Science, 8(C), 133-147. https://doi.org/10.1016/S0928-3420(01)80011-2

[26] Lage, M., \& Cantrell, C. L. (2009). Quantification of saffron (Crocus sativus L.) metabolites crocins, picrocrocin and safranal for quality determination of the spice grown under different environmental Moroccan conditions. Scientia Horticulturae, 121(3), 366-373. https://doi.org/10.1016/j.scienta.2009.02.017

[27] Liang, Y., Sun, W., Zhu, Y.-G., \& Christie, P. (2007). Mechanisms of silicon-mediated alleviation of abiotic stresses in higher plants: A review. Environmental Pollution, 147(2), 422-428. https://doi.org/10.1016/j.envpol.2006.06.008

[28] Ma, J. F. (2004). Characterization of the Silicon Uptake System and Molecular Mapping of the Silicon Transporter Gene in Rice. Plant Physiology, 136(2), 3284-3289. https://doi.org/10.1104/pp.104.047365

[29] Ma, J. F., Yamaji, N., \& Mitani-Ueno, N. (2011). Transport of silicon from roots to panicles in plants. Proceedings of the Japan Academy. Series B, Physical and Biological Sciences, 87(7), 377385. https://doi.org/10.2183/pjab.87.377

[30] Manivannan, A., Soundararajan, P., Muneer, S., Ko, C. H., \& Jeong, B. R. (2016). Silicon mitigates salinity stress by regulating the physiology, antioxidant enzyme activities, and protein expression in Capsicum annuum "Bugwang." BioMed Research International, 2016. https://doi.org/10.1155/2016/3076357

[31] Matichenkov V. and Bocharnikova E. (2004). Si in horticultural industry, in Production Practices and Quality Assessment of Food Crops. Production Practices and Quality Assessment of Food. Retrieved from http://link.springer.com/chapter/10.1007/1-4020-2536-X_9

[32] McElrone, A. J., Pockman, W. T., Martinez-Vilalta, J., \& Jackson, R. B. (2004). Variation in xylem structure and function in stems and roots of trees to $20 \mathrm{~m}$ depth. New Phytologist, 163(3), 507517. https://doi.org/10.1111/j.1469-8137.2004.01127.x

[33] Moussa, H. R. (2006). Influence of exogenous application of silicon on physiological response of salt-stressed maize (Zea mays L.). International Journal of Agriculture and Biology, 8(2), 293-297.

[34] Munns, R. (2005). Genes and salt tolerance: bringing them together. New Phytologist, 167(3), 645663. https://doi.org/10.1111/j.1469-8137.2005.01487.x

[35] Nabati, J., Kafi, M., Nezami, A., Moghaddam, P. R., Ali, M., \& Mehrjerdi, M. Z. (2011). Effect of salinity on biomass production and activities of some key enzymatic antioxidants in Kochia (Kochia scoparia). Pakistan Journal of Botany, 43(1), 539-548. 
[36] Neumann, D., \& Zur Nieden, U. (2001). Silicon and heavy metal tolerance of higher plants. Phytochemistry, 56(7), 685-692. https://doi.org/10.1016/S0031-9422(00)00472-6

[37] Ouzounidou, G., Giannakoula, A., Ilias, I., \& Zamanidis, P. (2016). Alleviation of drought and salinity stresses on growth, physiology, biochemistry and quality of two Cucumis sativus L. cultivars by Si application. Revista Brasileira de Botanica, 39(2), 531-539. https://doi.org/10.1007/s40415-016-0274-y

[38] Paul, D. (2013). Osmotic stress adaptations in rhizobacteria. Journal of Basic Microbiology, 53(2), 101-110. https://doi.org/10.1002/jobm.201100288

[39] Pitman, M. G., \& Läuchli, A. (2002). CHAPTER 1 GLOBAL IMPACT OF SALINITY AND AGRICULTURAL ECOSYSTEMS Agricultural losses caused by salinity are difficult to assess but estimated to be substantial and expected to increase with time . Secondary salinization of agricultural lands is particularl, 3-20.

[40] Razavi, B. M., \& Hosseinzadeh, H. (2015). Saffron as an antidote or a protective agent against natural or chemical toxicities. DARU Journal of Pharmaceutical Sciences, 23 (1), 1-9. https://doi.org/10.1186/s40199-015-0112-y

[41] Romani, A., Pinelli, P., Cantini, C., Cimato, A., \& Heimler, D. (2006). Characterization of Violetto di Toscana, a typical Italian variety of artichoke (Cynara scolymus L.). Food Chemistry, 95(2), 221-225. https://doi.org/10.1016/j.foodchem.2005.01.013

[42] Sahebi, M., Hanafi, M. M., Siti Nor Akmar, A., Rafii, M. Y., Azizi, P., Tengoua, F. F.,\&Shabanimofrad, M. (2015). Importance of silicon and mechanisms of biosilica formation in plants. BioMed Research International. https://doi.org/10.1155/2015/396010

[43] Sánchez-Vioque, R., Rodríguez-Conde, M. F., Reina-Ureña, J. V., Escolano-Tercero, M. A., Herraiz-Peñalver, D., \& Santana-Méridas, O. (2012). In vitro antioxidant and metal chelating properties of corm, tepal and leaf from saffron (Crocus sativus L.). Industrial Crops and Products, 39(1), 149-153. https://doi.org/10.1016/j.indcrop.2012.02.028

[44] Shahbaz, M., \& Ashraf, M. (2013). Improving Salinity Tolerance in Cereals. Critical Reviews in Plant Sciences, 32(4), 237-249. https://doi.org/10.1080/07352689.2013.758544

[45] Singh, A. K. (2004). The Physiology of Salt Tolerance in Four Genotypes of Chickpea during Germination, 6, 87-93.

[46] Sperry, J. S., Hacke, U. G., Oren, R., \& Comstock, J. P. (2002). Water deficits and hydraulic limits to leaf water supply. Plant, Cell and Environment, 25(2), 251-263. https://doi.org/10.1046/j.00168025.2001.00799.x

[47] Zhu, Y., \& Gong, H. (2014). Beneficial effects of silicon on salt and drought tolerance in plants. Agronomy for Sustainable Development, 34(2), 455-472. https://doi.org/10.1007/s13593-0130194-1

[48] Zhu, Z., Wei, G., Li, J., Qian, Q., \& Yu, J. (2004). Silicon alleviates salt stress and increases antioxidant enzymes activity in leaves of salt-stressed cucumber (Cucumis sativus L.). Plant Science, 167(3), 527-533. https://doi.org/10.1016/j.plantsci.2004.04.020

*Corresponding author.

E-mail address: bouzoubaa_zakia@yahoo.fr 